УДК 340.12:004.8

DOI: $10.21564 / 2663-5704.49 .229779$

Павленко Жанна Олександрівна, кандидат юридичних наук, доцент, доцент кафедри філософії, Національний юридичний університет

імені Ярослава Мудрого, м. Харків, Україна e-mail: zhannapavlenko4@gmail.com

ORCID ID: 0000-0001-6408-4299

\title{
ПРАВО В ЦИФРОВІЙ РЕАЛЬНОСТІ
}

Здійснено осмислення впливу процесу ичифровізації на право як таке. Показано, що поряд із перевагами цифрових технологій, зокрема штучного інтелекту, порушуються нові типи етичних проблем та питання справедливості. Обтрунтовано необхідність визначення підходів до розв 'язання нових завдань юридичної науки та вдосконалення нормативно-правової бази для захисту цифрових прав громадян.

Ключові слова: ициррова реальність, иифрровізація права, начіональна стратегія штучного інтелекту, штучний інтелект і право, технологічне відношення до юридичного знання.

Постановка проблеми. Об'єктивна сучасна реальність, яка пов'язана з технологічним проривом, характеризується тим, що в усьому світі йдуть процеси цифрової трансформації. Пріоритетна увага надається розвитку таких наскрізних цифрових технологій, як Інтернет речей, індустріальний Інтернет, штучний інтелект, хмарні обчислення, квантові та нові виробничі технології, компоненти робототехніки, кіберфізичні системи, технології обробки великого обсягу даних, бездротовий зв'язок, адитивні технології (3D-друк), блокчейн.

Під впливом цифровізації визначаються перспективи найближчого майбутнього, виникають нові галузі економіки, нові професії тощо. Це обумовлено колосальним зростанням обсягів даних, що збільшує потребу в цифровому середовищі, яке має забезпечувати доступ до великих масивів цифрової інформації, надійний захист персональних даних та конфіденційність. Особливо важливо це для систем, що використовують конфіденційні особисті дані. У зв'язку з чим виникає необхідність створення інформаційно-технологічної інфраструктури, що забезпечує доступ, обробку, передачу, мережеве зберігання масивів даних протягом тривалого часу та їх використання. Цей процес не зводиться лише до простого оцифровування даних. Ідеться також про розробку штучних інтелектуальних систем і баз даних, вивчення методів і засобів отримання, представлення, структурування і використання знань. 
Взаємозв'язок і вплив цифрових технологій на економічні та управлінські (у тому числі державно-управлінські) відносини вже очевидні, чого не можна сказати про їхню аналогічну взаємодію з правом. Якби наука змогла дати однозначну відповідь на питання про природу цих процесів, то це дозволило б об’єктивно оцінити масштаб і наслідки їхнього впливу на суспільство і різні сфери його життя.

У зв'язку з бурхливим розвитком цифрових технологій особливо актуальним $€$ питання врегулювання статусу та використання технологій штучного інтелекту. Ця обставина свідчить про необхідність і важливість пошуку відповідей на поставлене питання і націлює на активізацію та об'єднання зусиль наукової спільноти для вирішення відповідних завдань. Один із напрямів наукового пошуку полягає в доктринальному освоєнні нових явищ і процесів, що виникли і протікають у державно-правовій сфері під впливом цифровізації економіки, управління та права. Завданнями наукового пошуку є: осмислення впливу процесу цифровізації на державно-правову сферу життя суспільства; право як таке; оцінки трансформацій, які відбуваються, і виявлення тенденцій в їх динаміці; прогнозування стану цих явищ у майбутньому; постановки фундаментальних і прикладних завдань юридичної науки в частині доктринального освоєння закономірностей розвитку й функціонування права, державно-правової сфери життя суспільства в умовах цифрової реальності, визначення підходів до їхнього вирішення.

Аналіз останніх досліджень і публікацій дозволяє констатувати, що наукові доробки стосовно означеної проблематики здійснюються здебільшого в межах економічних, політичних, комп'ютерних, правових наук, хоча проблеми та перспективи цифровізації права вимагають насамперед глибокого й ретельного філософського, зокрема філософсько-правового, осмислення. Правові та економічні аспекти цифровізації суспільства були предметом розгляду в працях таких науковців: О. Архипської, О. Вишневського, О. Баранова, В. Брижко, О. Вінник, С. Дзюби, М. Кузьміної, Н. Левицької, В. Ляшенко, А. Семенченко, О. Сосніна, В. Цимбалюка, М. Швеця та ін. Дослідженню проблем інтелектуалізації суспільства, створення й упровадження нових технологій, що базуються на ефективному використанні знань у нашій країні, була присвячена низка робіт соціально-філософського спрямування, логікогносеологічного, філософсько-політичного, філософсько-правового, економічного, когнітивно-інформаційного, що, зокрема, знаходить своє відображення в працях: В. Андрущенка, I. Бойченка, О. Данильяна, О. Дзьобаня, В. Кушерця, С. Максимова, А. Уйомова, О. Щербини, О. Юркевич та ін. Можливості, особливості, перспективи та межі задіяння цифрових технологій 
у професійній юридичній практиці, юридичній експертній діяльності висвітлювали у своїх роботах наступні іноземні науковці: Н. Адам (Nabil R. Adam), Д. Сартор (Giovanni Sartor), Д. Гарсіа (Dennis Garcia), М. Багарік (Mirko Bagaric), Л. Брантінг (Luther Branting), Е. Д’Амато (Anthony D’Amato), Е. Джонглоуд (Anthonie Jongbloed), К. Ешлі (Kevin Ashley), М. Ж. Холл (Maria Jean J. Hall), Д. Железников (John Zeleznikow), Д. Калабро (Domenico Calabro), Л. Каменер (Larry Kamener), Ф. Леві (Frank S. Levy), Ф. Лейт (Philip Leith), Д. МакДжінніс (John O. McGinnis), Х. Накад-Вестстрат (Henriëtte NakadWeststrate), Р. Пірс (Russell G. Pearce), Д. Рімас (Dana Remus), Е. Ріссланд (Edvina Rissland), А.-Б. Салем (Abdel-Badeeh M. Salem), М. Сімажкевіч (Maria Siemaszkiewicz), Е. Страньерi (Andrew Stranieri), Н. Стоббс (Nigel Stobbs), Т. Сурдин (Tania Sourdin), Д. Томпсон (Darin Thompson), Х. ван ден Херік (Јаap van den Herik), Д. Хантер (Dan Hunter), Р. Холовчак (Richard D. Holowczak) та iн.

Формулювання цілей. Результати досліджень цих проблем дають можливість зазначити, що в цілому системне наукове осмислення складної, об'ємної і багатоаспектної проблеми з'ясування впливу цифрових технологій на трансформацію правових норм, правознавчої науки і юридичної освіти тощо потребують подальшого ретельного вивчення. Тому метою цієї статті є філософсько-правове осмислення впливу цифровізації на державно-правову сферу життя суспільства і право як таке.

Виклад основного матеріалу. Цифрові технології обіцяють підвищити ефективність та результативність цілих секторів економіки, в тому числі надання державних послуг. Системи штучного інтелекту, спрямовані на підтримку ухвалення рішень, доповнюють людські навички управління знаннями за допомогою комп'ютерних засобів. Системи, спрямовані на підтримку ухвалення рішень, допомагають особам, що приймають рішення, поліпшити їхню продуктивність, тоді як інструменти ухвалення рішень автоматизують ці процеси [15, p. 74-75]. Одним із практичних аспектів цифровізації є прояв можливості держави надавати різного роду послуги. Зокрема, це отримання громадянами довідок, запитів, заяв, відповідей на запити в електронному вигляді, електронні платежі тощо. Іншими практичними аспектами, за умови розумного застосування цих технологій, є можливість покращити добробут у сферах освіти, громадської безпеки, здоров'я. Окрім цього, цифровізація також може допомогти вирішити нагальні глобальні проблеми, такі як зміна клімату й ширший доступ до медичного обслуговування та мобільності.

Україна не стоїть осторонь цих процесів (див. [10]). Так, у 2015 р. було надано старт сфері надання електронних адміністративних послуг в Україні. У липні 2015 р. на сайті Державної архітектурно-будівельної інспекції України 
презентували електронні послуги у сфері будівництва: реєстрацію повідомлень і декларацій про початок підготовчих робіт; про початок будівельних робіт; реєстрацію декларацій про готовність об'єкта до експлуатації та подання відомостей для отримання ліцензії на господарську діяльність щодо створення об'єктів архітектури [1]. У грудні 2020 р. Міністр цифрової трансформації М. Федоров під час онлайн-конференції «Досягнення та виклики у сфері адміністративних послуг 2020-2021» повідомив, що до 2024 р. Міністерство планує перевести 100\% публічних послуг в онлайн Урядовий портал [3].

У той же час, на думку багатьох дослідників, поряд із перевагами цифрових технологій, зокрема штучного інтелекту, порушуються нові типи етичних проблем, а саме дотримання стандартів юридичної етики системами штучного інтелекту та питання справедливості, головними серед яких $є$ питання поваги прав людини та демократичних цінностей, а також небезпека перенесення упереджень з аналогового у цифровий світ. Науковці пов'язують правові проблеми застосування технологій штучного інтелекту в юридичній практиці з такими питаннями (див.: [14; 20]): забезпечення конфіденційності даних; доступу до конфіденційної інформації правоохоронних органів; відсутності нормативної бази регулювання застосування систем штучного інтелекту в юридичній практиці; захисту інтелектуальної власності; оцінки ризиків використання систем штучного інтелекту юристом під час роботи 3 клієнтом; інших потенційних проблем відповідальності юриста; небезпеки несанкціонованого доступу й модифікації зловмисниками систем штучного інтелекту; пошкодження систем штучного інтелекту шкідливими вірусними програмами; порушення термінів надання консультації від систем штучного інтелекту у випадку технічних проблем тощо. Тому розробка систем, які прозоро застосовують штучний інтелект та відповідають за їхні результати, $\epsilon$ критично важливою. Системи штучного інтелекту повинні функціонувати належним чином і безпечно.

На думку експертів, неврегульованість в Україні багатьох політико-правових питань, пов'язаних із бурхливим розвитком інформаційно-комунікаційної сфери з появою цифрових технологій, набула ознак небезпеки [8]. Очевидно, що перетворення в соціумі, які пов'язані із цими процесами, потребують нових підходів до питань розробки національної політики щодо цифровізації суспільства, яка має спиратися на міжнародні угоди.

У червні 2020 р. з метою пропаганди відповідального використання штучного інтелекту, яке поважає права людини та демократичні цінності, було започатковано проект під назвою «Глобальне партнерство з питань штучного інтелекту (GPAI)», який об’єднує експертів із промисловості, уряду, грома- 
дянського суспільства та наукових кіл для просування найсучасніших дослідницьких та пілотних проектів щодо пріоритетів штучного інтелекту. Глобальне партнерство з питань штучного інтелекту було задумано Канадою та Францією під час їхніх головувань у G7 та на момент його заснування включало 13 інших членів-засновників: Австралію, Свросоюз, Німеччину, Індію, Італію, Японію, Корею, Мексику, Нову Зеландію, Сінгапур, Словенію, Великобританію та США.

Міжнародне співробітництво щодо цих процесів відбувається на форумах Організації економічного співробітництва та розвитку (ОЕСР)1 ${ }^{1}$, G7, G20, Європейського Союзу, Ради Європи та Організації Об'єднаних Націй з питань освіти та науки (ЮНЕСКО). У вересні 2019 р. Комітет міністрів Ради Свропи (Р€) створив Спеціальний комітет зі штучного інтелекту, який вивчає доцільність розробки правової бази для створення та застосування штучного інтелекту на основі стандартів РЄ щодо прав людини, демократії та верховенства права. У квітні 2020 р. Комітет міністрів РС видав набір настанов, у яких закликав уряди застосовувати запобіжний підхід до розробки та використання алгоритмічних систем та закликав прийняти законодавство, політику та практику, які повністю поважають права людини [11].

У своїй «Дорожній карті» для цифрового співробітництва Генеральний секретар ООН закликав створити багатосторонній дорадчий орган із питань глобального співробітництва в галузі штучного інтелекту. Орган надаватиме вказівки щодо штучного інтелекту, який заслуговує на довіру, базується на правах людини, є безпечним, стійким та сприяє миру, об'єднавши різноманітну групу відповідних суб'єктів для вирішення питань, пов'язаних із включенням, координацією, побудовою, обміном і просуванням найкращих практик, а також обміном думками щодо спроб стандартизації штучного інтелекту.

Багато інших установ ООН також беруть участь в ініціативах для вирішення проблем зі штучного інтелекту (див. [21]). ЮНЕСКО розпочала глобальний діалог щодо етики штучного інтелекту через його складність та вплив на суспільство та людство. У листопаді 2019 р. 40-ва Генеральна конференція ЮНЕСКО доручила організації розробити рекомендацію щодо етики штучного інтелекту, яка буде розглядатися для прийняття в листопаді 2021 р. [19].

Важливу роботу щодо питань застосовування штучного інтелекту здійснює OЕСР, яка об'єднує 34 країни світу, більшість із яких є країнами з високим доходом громадян та високим індексом людського розвитку. 31997 р. Україна співпрацює із цією міжнародною організацією, у 2013 р. Кабінетом Міністрів України було затверджено план дій щодо поглиблення співробітництва між Україною та ОЕСР [6].

\footnotetext{
${ }^{1}$ Organisation for Economic Cooperation and Development (OECD).
} 
Провідні країни світу постійно приділяють увагу проблематиці стратегій і планів розвитку цифрової економіки. Про це свідчить низка програм і напрацювань у межах OECP і G20, їх об’єднує кілька напрямів, які можна застосувати до більшості країн. До них відносяться наступні: створення сучасної інфраструктури зв'язку, центрів зберігання і обробки даних; сприяння вільному обміну інформацією; розширення спектра інформаційно-комунікаційних послуг; упровадження нових інтелектуальних мереж, платформ і технологій одночасно із забезпеченням їхньої інтероперабельності (функціональної сумісності); розвиток електронної торгівлі; скасування обмежень, що заважають веденню бізнесу; стимулювання підприємницької ініціативи і фінансування в ІКТ; надання пільг малому та середньому бізнесу; підвищення рівня інформаційної безпеки та довіри користувачів до інтернет-сервісів; підготовка фахівців і підвищення загального рівня комп'ютерної грамотності. Можна також виділити основні сфери, в яких ІКТ знайшли найбільш широке застосування. До них належать: розумні міста, сільське господарство, логістика та державне управління; цифрова охорона здоров'я; інтелектуальні енергетичні мережі (Smart Grid) і транспортні системи; фінансові послуги. За різноманіття підходів до формування державних стратегій розвитку цифрової економіки з огляду на свою масштабність найбільший практичний і дослідницький інтерес становлять відповідні програмні документи крупних міжнародних гравців - США, Китаю і СС [4, с. 212].

У багатьох країнах світу вже прийняті або перебувають на стадії розробки національні стратегії щодо переходу на цифрову економіку. У 2019 р. ОЕСР виробила перелік заходів, необхідних для успішного впровадження цифрового порядку урядами, серед яких у третьому пункті зазначено: «Оновити нормативно-правову базу для захисту цифрових прав громадян та включити потенційні наслідки збільшення використання нових технологій та даних в існуючі правові гарантії» [18].

У травні 2019 р. країни ОЕСР прийняли Принципи штучного інтелекту [16], які спираються на п'ять принципів, що базуються на цінностях відповідального управління надійним штучним інтелектом і посилаються на політичні рекомендації, що стосуються національної політики та міжнародного співробітництва в цій сфері. Цим кроком країни ОЕСР погодилися забезпечити надійні, орієнтовані на людину високотехнологічні системи. У липні 2019 р. Комітет з питань політики цифрової економіки ОЕСР погодився сформувати мультидисциплінарну та багатосторонню мережу експертів ОЕСР з питань штучного інтелекту для розробки практичних указівок щодо впровадження Принципів штучного інтелекту. Для реалізації цих Принципів необхідна стратегія національної політики, яка включала б методи та засоби заохочення інвестицій у відповідні дослідження та розробки. 
У зв'язку з трансформаціями, які відбуваються завдяки залученню технологій штучного інтелекту в життя суспільства, виникає необхідність у розробці стратегічних документів, які будуть регулювати цей напрям. Такі документи повинні бути гнучкими і розробленими на основі врахування максимальної кількості даних, а також забезпечувати вільний розвиток інноваційних технологій і попереджати можливі ризики.

Останнім часом розвинені країни світу, зокрема, Канада, Великобританія та США, почали проводити розвідки з питань політики та видавати щорічні звіти для оцінки реалізації своїх національних стратегій щодо штучного інтелекту. У 2017 р. Канада стала першою країною, яка запустила національну стратегію штучного інтелекту. До квітня 2020 р. понад 60 країн мали національну політику щодо штучного інтелекту, а інші наслідували їхній приклад. У липні 2020 р. Італія була останньою країною, яка прийняла національну стратегію щодо штучного інтелекту.

Для нагляду за реалізацією національних стратегій та політики щодо штучного інтелекту кілька країн створили так звані Обсерваторії штучного інтелекту, зокрема Міжнародну Обсерваторію Квебека із соціальних наслідків штучного інтелекту в Канаді; Французьку Обсерваторію з економічного та соціального впливу штучного інтелекту; Італійську Обсерваторію зі штучного інтелекту; Обсерваторію та Форум Чеської Республіки. У березні 2020 р. Міністерство праці Німеччини запустило KI-Observatorium, яка має на меті допомогти реалізувати деякі стратегії штучного інтелекту в Німеччині та заохотити відповідальне, орієнтоване на людей та спільне використання цих технологій у сфері праці та суспільства.

Європейський Союз запланував спільний моніторинг із метою підведення підсумків досягнень та оцінки потенційних дій для узгодженого плану на найближчий час. AI Watch - це спільна програма DG Connect та Спільного дослідницького центру (JRC) для моніторингу й оцінки поширення та впливу штучного інтелекту в Свропі. Вони розробляють показники з державами-членами, щоб пропорційно розраховувати, відстежувати, націлювати та оцінювати інвестиції.

Штучний інтелект обговорювався у 2020 р. в рамках Робочої групи з питань цифрової економіки G20, а також під час надзвичайної зустрічі міністрів 3 питань цифрової економіки G20, на якій було визнано потенційний внесок штучного інтелекту у боротьбу з пандемією [12]. У 2020 р. президентство Саудівської Республіки G20 спрямувало роботу штучного інтелекту в напрямку розвитку політики реалізації можливостей XXI ст. для всіх [17]. Ця робота побудована на спадщині японського головування у 2019 р., у рамках якого 
G20 прийняла принципи штучного інтелекту, орієнтовані на людину, що випливають із Принципів штучного інтелекту ОЕСР.

В Україні початок інституційно-правового оформлення розвитку цифрової економіки було покладено Розпорядженням Кабінету Міністрів України «Про схвалення Стратегії розвитку інформаційного суспільства в Україні» в 2013 р. Однак, на думку науковців, особливість українського цифрового розвитку полягає в тому, що індивідуальні користувачі і бізнес значно випереджають державу і промисловість [2, с. 57]. У червні 2015 р. Україна приєдналася до Декларації першого засідання міністрів «Східного партнерства ЄС» 3 питань цифрової економіки [13], на якому цифрова економіка була визнана сферою з невикористаним потенціалом як для СС, так і для шести країн-партнерів. Наступним кроком у нашій країні стало розроблення концептуальних засад «Цифрового порядку денного України - 2020», який визначав ключові зав-дання, першочергові сфери, ініціативи та проекти «цифровізації» України. У 2017 р. прийнято Закон України «Про електронні довірчі послуги», який покликаний сприяти побудові цифрової інфраструктури довіри, що є важливим елементом цифрової економіки. 17 січня 2018 р. розпорядженням Кабінету Міністрів України було схвалено Концепцію розвитку цифрової економіки та суспільства України на 2018-2020 роки та затверджено план заходів щодо іiі реалізації. Головною метою в цьому документі визнається реалізація прискореного сценарію цифрового розвитку, який передбачає усунення законодавчих, інституційних, фіскальних та інших перешкод, які заважають розвитку цифрової економіки; впровадження стимулів та мотивацій для заохочення бізнесу та індустрій економіки в цілому до цифровізації; створення попиту та формування потреб серед громадян до цифровізації, насамперед через упровадження державою масштабних проектів цифрових трансформацій, зокрема, на базі сучасних моделей державно-приватного партнерства; створення та розвиток цифрових інфраструктур як основи використання переваг цифрового світу в повсякденному житті та платформи для досягнення ефективності економіки взагалі; розвиток та поглиблення цифрових компетенцій громадян для забезпечення їхньої готовності до використання цифрових можливостей, а також подолання супутніх ризиків; розвиток цифрового підприємництва, створення відповідних (у тому числі аналогових) інфраструктур для підтримки та розвитку інноваційної діяльності, впровадження механізмів фондування, стимулювання та підтримки [7]. У лютому 2020 р. у відкритому доступі з'явився додаток державних цифрових послуг «Дія», який надає можливість отримати державні послуги онлайн як громадянам, так і бізнесу [5]. 
Визнаючи високу значимість зроблених кроків на цьому шляху, необхідно зазначити, що питання розвитку цифрової економіки та суспільства України повною мірою відповідають умовам сьогодення, не достатньо враховуються трансформації, що намітилися і що відбуваються в даний час як у самому праві, так і у сфері правового регулювання під впливом цифровізації. Цифрові технології здатні змінювати образ права, впливати на його регулятивний потенціал і ефективність, відкривати дорогу або блокувати його дію в нових вимірах соціальної реальності [9, с. 156-159]. Вектори і межі таких змін до кінця не зрозумілі, проте заперечувати можливість їхнього настання і не брати до уваги в ході реалізації такого масштабного проекту, як перехід до цифрової економіки, буде помилкою. Традиційне, а не цифрове бачення права, юридичних технологій і окремих видів юридичної діяльності законодавцями є наслідком відсутності відповідних наукових розробок, які виявлятимуть і зможуть пояснити вплив процесу цифровізації на право і правову сферу життя суспільства. Практична потреба в таких дослідженнях зараз як ніколи велика. 3 метою iii задоволення науковцям слід активізувати роботу в цьому напрямку.

Висновки. Нова цифрова реальність висуває нові вимоги до правової науки і юридичної практики, що стосуються в тому числі розробки ефективних інструментів і моделей правового регулювання різних сфер суспільного життя. У сучасних умовах право стає не тільки засобом, інструментом, який забезпечує цифровізацію економіки, управління та інших сегментів соціального буття, але й об'єктом впливу цифровізації. Із розвитком цифрових технологій загострюється протиріччя між потребою в якісних як із точки зору форми, так і змісту нормативних правових актів, а також здатністю ії задовольнити в короткі терміни. Завданням держави є як забезпечення сприятливих умов, що сприяють цифровізації, так і створення можливостей для їх реалізації.

\section{ЛIТЕРАТУРА}

1. В Україні запрацювали електронні адмінпослуги у сфері будівництва. Урядовий портал. 16.07.2015. URL: https://www. kmu.gov.ua/news/248336521 (дата звернення: 01.02.2021).

2. Жекало Г. І. Цифрова економіка України: проблеми та перспективи розвитку. Науковий вісник Ужгородського наиіонального університету. 2019. Вип. 26, ч. 1. C. 56-60. URL: http://www.visnyk-econom.uzhnu.uz.ua/archive/26_1_2019ua/12.pdf (дата звернення: 06.02.2021).

3. Михайло Федоров анонсував ключові напрямки у сфері адміністративних послуг. Урядовий портал: Міністерство иифрової трансформаиї̈ України. 09.12.2020. URL: https://www.kmu.gov.ua/news/mihajlo-fedorov-anonsuvav-klyuchovi-napryamkiu-sferi-administrativnih-poslug (дата звернення: 01.02.2021). 
4. Пищуліна О. Цифрова економіка: тренди, ризики та соціальні детермінанти. Київ: Центр Разумкова: Заповіт, 2020. 274 c. URL: https://razumkov.org.ua/uploads/ article/2020_digitalization.pdf (дата звернення: 01.02.2021).

5. Портал «Цифрова держава Дія». URL: https://plan2.diia.gov.ua (дата звернення: 06.02.2021).

6. Про затвердження плану дій щодо поглиблення співробітництва між Україною та Організацією економічного співробітництва та розвитку на 2013-2016 роки: Розпорядження Кабінету Міністрів України від 06.02.2013 № 132-р. Урядовий кур’єр. 2013. 3 квіт. (№62).

7. Про схвалення Концепції розвитку цифрової економіки та суспільства України на 2018-2020 роки та затвердження плану заходів щодо іiі реалізації: Розпорядження Кабінету Міністрів України від 17.01.2018 №67-р. Урядовий кур ’єр. 2018. 11 трав. (№ 88).

8. Соснін О. Цифровізація як нова реальність України. LexInform: Юридичні новини України. 18.01.2020. URL: https://lexinform.com.ua/dumka-eksperta/ tsyfrovizatsiya-yak-nova-realnist-ukrayiny/ (дата звернення: 06.02.2021).

9. Сучасне суспільство, людина, право в умовах глобальних трансформацій: монографія / О. Г. Данильян, О. П. Дзьобань, С. Б. Жданенко та ін.; за ред. О. Г. Данильяна. Харків: Право, 2020. 344 с.

10. Федулова Л. І. Аналітична записка «Про інвестиційну політику розвитку цифрової економіки і суспільства: світові тенденції та виклики для України». Інститут експертно-аналітичних та наукових досліджень Національної академії державного управління при Президентові України. URL: http://academy.gov.ua/pages/ dop/198/files/e8d8e315-e366-4105-be1b-a3344df3a5da.pdf (дата звернення: 08.02.2021).

11. Council of Europe, Joint Statement on the right to data protection in the context of the COVID-19 pandemic by Alessandra Pierucci, Chair of the Committee of Convention 108 and Jean-Philippe Walter, Data Protection Commissioner of the Council of Europe. Council of Europe. Strasbourg, 30.03.2020. URL: https: //www.coe.int/en/web/dataprotection/statement-by-alessandra-pierucci-and-jean-philippe-walter (дата звернення: 08.02.2021).

12. Extraordinary G20 Digital Economy Ministerial Meeting: COVID-19 Response Statement: Virtual meeting, University of Toronto, 30.04.2020. URL: http://www.g20. utoronto.ca/2020/2020-g20-digital-0430.html (дата звернення: 07.02.2021).

13. First Eastern Partnership Ministerial Meeting on the Digital Economy. European Commission. 11.06.2015. URL: https://ec.europa.eu/digital-single-market/en/news/ first-eastern-partnership-ministerial-meeting-digital-economy (дата звернення: 08.02.2021).

14. Garcia D. Preparing for Artificial Intelligence in the Legal Profession. The Lexis Practice Advisor Journal. URL: https://www.lexisnexis.com/lexis-practice-advisor/ the-journal/b/lpa/posts/preparing-for-artificial-intelligence-in-the-legal-profession (дата звернення: 30.01.2021). 
15. Lodder A., Zeleznikow J. Artificial Intelligence and Online Dispute Resolution. Online Dispute Resolution: Theory and Practice / ed. by M. A. Wahab, E. Katsh, D. Rainey. The Hague (Netherlands): Eleven International Publishing, 2012. P. 73-94. URL: https://www.mediate.com/pdf/lodder_zeleznikow.pdf (дата звернення: 02.02.2021).

16. OECD AI Principles overview. OECD AI Policy Observatory, May 2019. URL: https:// www.oecd.ai/ai-principles (дата звернення: 01.02.2021).

17. Realizing Opportunities of the 21st Century for All. Summit'Leaders G20. Riyadh, 22-21 November 2020. URL: http://www.g20.utoronto.ca/2020/2020-Presidency_ Agenda-V5.pdf (дата звернення: 03.02.2021).

18. Strengthening Digital Government. OECD, March 2019. URL: https://www.oecd.org/ going-digital/strengtheningdigital-government.pdf (дата звернення: 08.02.2021).

19. Toward a draft text of a Recommendation on the Ethics of Artificial Intelligence: working document. UNESCO. Virtual discussion of the Ad Hoc Expert Group (AHEG) for the Preparation of a Draft Text of a Recommendation on the Ethics of Artificial Intelligence. Paris, 10 April 2020. 60 p. URL: https://unesdoc.unesco.org/ ark:/48223/pf0000373199 (дата звернення: 09.02.2021).

20. Verheij B. Artificial intelligence as law. Presidential address to the seventeenth international conference on artificial intelligence and law. Artificial intelligence and law. 2020. No. 28. P. 181-206. DOI: https://doi.org/10.1007/s10506-020-09266-0 (дата звернення: 09.02.2021).

21. World Telecommunication/ICT Indicators Database 2020 (24th Edition/ December 2020). The International Telecommunication Union (ITU). Geneva, January 2021. URL: http://www.itu.int/pub/D-IND-WTID.OL (дата звернення: 01.02.2021).

\section{REFERENCES}

1. V Ukraini zapratsiuvaly elektronni adminposluhy u sferi budivnytstva. Uriadovyi portal. 16.07.2015. URL: https://www. kmu.gov.ua/news/248336521 (data zvernennia: 01.02.2021) [in Ukrainian].

2. Zhekalo, H. (2019). Tsyfrova ekonomika Ukrainy: problemy ta perspektyvy rozvytku. Naukovyi visnyk Uzhhorodskoho natsionalnoho universytetu, Vyp. 26, ch. 1, 56-60. URL: http://www.visnyk-econom.uzhnu.uz.ua/ archive/26_1_2019ua/12.pdf [in Ukrainian].

3. Mykhailo Fedorov anonsuvav kliuchovi napriamky u sferi administratyvnykh posluh. Uriadovyi portal: Ministerstvo tsyfrovoi transformatsii Ukrainy. 09.12.2020. URL: https://www.kmu.gov.ua/news/mihajlo-fedorov-anonsuvav-klyuchovi-napryamki-usferi-administrativnih-poslug [in Ukrainian].

4. Pyshchulina, O. (2020). Tsyfrova ekonomika: trendy, ryzyky ta sotsialni determinanty. Kyiv: Tsentr Razumkova: Zapovit. URL: https://razumkov.org.ua/uploads/article/2020_ digitalization.pdf [in Ukrainian].

5. Portal «Tsyfrova derzhava Diia». URL: https://plan2.diia.gov.ua [in Ukrainian].

6. Pro zatverdzhennia planu dii shchodo pohlyblennia spivrobitnytstva mizh Ukrainoiu ta Orhanizatsiieiu ekonomichnoho spivrobitnytstva ta rozvytku na 2013-2016 roky: 
Rozporiadzhennia Kabinetu Ministriv Ukrainy vid 06.02.2013 № 132-r. Uriadovyi kurier. 2013. 3 kvit. (№ 62) [in Ukrainian].

7. Pro skhvalennia Kontseptsii rozvytku tsyfrovoi ekonomiky ta suspilstva Ukrainy na 2018-2020 roky ta zatverdzhennia planu zakhodiv shchodo yii realizatsii: Rozporiadzhennia Kabinetu Ministriv Ukrainy vid 17.01.2018 №67-r. Uriadovyi kurier. 2018. 11 trav. (№ 88) [in Ukrainian].

8. Sosnin, O. (2020). Tsyfrovizatsiia yak nova realnist Ukrainy. LexInform: Yurydychni novyny Ukrainy. URL: https://lexinform.com.ua/dumka-eksperta/tsyfrovizatsiya-yaknova-realnist-ukrayiny/ [in Ukrainian].

9. Danylian, O., Dzoban, O., Zhdanenko, S. et al. (2020). Suchasne suspilstvo, liudyna, pravo v umovakh hlobalnykh transformatsii: monohrafiia. Danylian O. H., (Ed.). Kharkiv: Pravo [in Ukrainian].

10. Fedulova, L. Analitychna zapyska «Pro investytsiinu polityku rozvytku tsyfrovoi ekonomiky i suspilstva: svitovi tendentsii ta vyklyky dlia Ukrainy». Instytut ekspertnoanalitychnykh ta naukovykh doslidzhen Natsionalnoi akademii derzhavnoho upravlinnia pry Prezydentovi Ukrainy. URL: http://academy.gov.ua/pages/dop/198/files/ e8d8e315-e366-4105-be1b-a3344df3a5da.pdf [in Ukrainian].

11. Council of Europe, Joint Statement on the right to data protection in the context of the COVID-19 pandemic by Alessandra Pierucci, Chair of the Committee of Convention 108 and Jean-Philippe Walter, Data Protection Commissioner of the Council of Europe. Council of Europe. Strasbourg, 30.03.2020. URL: https:/www.coe.int/en/web/dataprotection/statement-by-alessandra-pierucci-and-jean-philippe-walter [in English].

12. Extraordinary G20 Digital Economy Ministerial Meeting: COVID-19 Response Statement: Virtual meeting, University of Toronto, 30.04.2020. URL: http://www.g20.utoronto.ca/2020/2020-g20-digital-0430.html [in English].

13. First Eastern Partnership Ministerial Meeting on the Digital Economy. European Commission. 11.06.2015. URL: https://ec.europa.eu/digital-single-market/en/news/ first-eastern-partnership-ministerial-meeting-digital-economy [in English].

14. Garcia, D. (2016). Preparing for Artificial Intelligence in the Legal Profession. The Lexis Practice Advisor Journal. URL: https://www.lexisnexis.com/lexis-practiceadvisor/the-journal/b/lpa/posts/preparing-for-artificial-intelligence-in-the-legalprofession [in English].

15. Lodder, A., Zeleznikow, J. (2012). Artificial Intelligence and Online Dispute Resolution. Online Dispute Resolution: Theory and Practice. Eds: Wahab M. A., Katsh E., Rainey D. The Hague (Netherlands): Eleven International Publishing, 73-94. URL: https://www.mediate.com/pdf/lodder_zeleznikow.pdf [in English].

16. OECD AI Principles overview. OECD AI Policy Observatory, May 2019. URL: https:// www.oecd.ai/ai-principles [in English].

17. Realizing Opportunities of the 21 st Century for All. Summit' Leaders G20. Riyadh, 22-21 November 2020. URL: http://www.g20.utoronto.ca/2020/2020-Presidency_ Agenda-V5.pdf [in English].

18. Strengthening Digital Government. OECD, March 2019. URL: https://www.oecd.org/ going-digital/strengtheningdigital-government.pdf [in English]. 
19. Toward a draft text of a Recommendation on the Ethics of Artificial Intelligence: working document. UNESCO. Virtual discussion of the Ad Hoc Expert Group (AHEG) for the Preparation of a Draft Text of a Recommendation on the Ethics of Artificial Intelligence. Paris, 10 April 2020. 60 p. URL: https://unesdoc.unesco.org/ ark:/48223/pf0000373199 [in English].

20. Verheij, B. (2020). Artificial intelligence as law. Presidential address to the seventeenth international conference on artificial intelligence and law. Artificial intelligence and law, 28, 181-206. DOI: https://doi.org/10.1007/s10506-020-09266-0 [in English].

21. World Telecommunication/ICT Indicators Database 2020 (24th Edition/ December 2020). The International Telecommunication Union (ITU). Geneva, January 2021. URL: http://www.itu.int/pub/D-IND-WTID.OL [in English].

Павленко Жанна Александровна, кандидат юридических наук, доцент, доцент кафедры философии, Национальный юридический университет

имени Ярослава Мудрого, г. Харьков, Украина

\section{ПРАВО В ЦИФРОВОЙ РЕАЛЬНОСТИ}

Осуществлено осмысление влияния процесса иифровизации на право как таковое. Показано, что наряду с преимуществами цицровых технологий, в частности искусственного интеллекта, возникают новые типь этических проблем и вопросы справедливости. Обоснована необходимость определения подходов к решению новых задач юридической науки и совершенствования нормативно-правовой базы для защитты циифровых прав граждан.

Ключевые слова: ицирровая реальность, иифровизация права, национальная стратегия искусственного интеллекта, искусственный интеллект и право, технологическое отношение к юридическому знанию.

Pavlenko Zhanna Oleksandrivna, $\mathrm{PhD}$ in Law, Associate Professor, Associate Professor of the Department of Philosophy, Yaroslav Mudryi National Law University,

Kharkiv, Ukraine

\section{LAW IN DIGITAL REALITY}

Problem setting. Due to the rapid development of digital technologies, the issue of status settlement and the use of artificial intelligence technologies is especially relevant. This fact indicates the need and importance of finding answers to the question and aims to intensify and unite the efforts of the scientific community to address relevant issues. One of the areas of scientific research is the doctrinal development of new phenomena and 
processes that have arisen and are taking place in the state and legal sphere under the influence of digitalization of economics, management and law. The tasks of scientific research are to comprehend the impact of the digitization process on the state and legal sphere of society; law as such; assessment of the transformations that are taking place and identification of trends in their dynamics; forecasting the state of these phenomena in the future; formulation of fundamental and applied problems of legal science in terms of doctrinal development of the laws of development and functioning of law, state and legal sphere of society in the conditions of digital reality, determination of approaches to their solution.

Recent research and publications analysis. An analysis of recent research and publications shows that scientific research on this issue is carried out mainly within the economic, political, computer, legal sciences, although the problems and prospects of digitization of law require a deep and thorough philosophical, including philosophical and legal understanding. The rapid development of new technologies, in particular artificial intelligence technologies, the Internet of Things, cloud technologies, etc., is contributing to changes in current legislation. Today, advanced economies are already pondering the question of regulating the status and use of AI technologies. While these are only the first bold steps, in the future, all of these can affect global changes in the legal system-perhaps full-fledged comprehensive institutions of law, even the branches of law.

Paper objective. The purpose of this article is a philosophical and legal understanding of the impact of digitalization on the state and legal sphere of society and law as such.

Paper main body. One of the practical aspects of digitalization is the manifestation of the state's ability to provide various services. If necessary, citizens receive certificates, records, statements, responses to electronic inquiries, electronic payments. Other practical aspects, provided that these technologies are used wisely, can improve welfare in education, public safety, and health. In addition, digital imaging can also help address common global issues, such as climate change and greater access to health care and mobility.

At the same time, according to many researchers, along with the benefits of digital technologies, including artificial intelligence, new types of ethical issues are being raised, namely compliance with legal ethics standards by artificial intelligence systems and justice, the most important of which are respect for human rights and democratic values. , as well as the danger of transferring prejudices from the analog to the digital world. Researchers have linked the legal challenges of using artificial intelligence technologies in legal practice to a number of issues. In particular, with such as: ensuring data confidentiality; access to confidential law enforcement information; lack of regulatory framework for the use of artificial intelligence systems in legal practice; protection of intellectual property; risk assessment of the use of artificial intelligence systems by a lawyer when working with a client; other potential problems of lawyer's liability; dangers of unauthorized access and modification of artificial intelligence systems by attackers; damage to artificial intelligence systems by malicious virus programs; violation of the terms of providing advice from artificial intelligence systems in case of technical problems, etc. Therefore, the development of systems that transparently use artificial intelligence and are responsible for their results is critical. Artificial intelligence systems must function properly and safely. 
According to experts, the unresolved in Ukraine of many political and legal issues related to the rapid development of the information and communication sphere with the advent of digital technologies has become dangerous. It is obvious that the transformations in society associated with these processes require new approaches to the development of national policies for the digitalization of society, which should be based on international agreements. Due to these transformations, there is a need to develop strategic documents that will regulate this area. These documents should be flexible and designed to take into account the maximum amount of data, as well as ensure the free development of innovative technologies and prevent possible risks.

Issues of development of the digital economy and society of Ukraine do not fully meet today's conditions, not enough account is taken of the transformations that have emerged and are currently taking place both in law and in the field of legal regulation under the influence of digitalization. Digital technologies are able to change the image of law, to influence its regulatory potential and efficiency, to open the way or to block its action in new dimensions of social reality. Traditional rather than digital vision of law, legal technologies and certain types of legal activity by legislators is a consequence of the lack of relevant scientific developments that will identify and explain the impact of the digitization process on the law and the legal sphere of society. The practical need for this kind of research is now greater than ever. In order to satisfy it, scientists should intensify work in this direction.

Conclusions of the research. The new digital reality puts forward new requirements for legal science and legal practice, including the development of effective tools and models of legal regulation of various spheres of public life. In modern conditions, law becomes not only a means, a tool that provides digitalization of the economy, government and other segments of social life, but also the object of digitalization. With the development of digital technologies, the contradiction between the need for quality both in terms of form and content of regulations, as well as the ability to meet it in a short time. The task of the state is both to provide favorable conditions conducive to digitalization and to create opportunities for their implementation.

Keywords: digital reality, digitalization of law, national strategy of artificial intelligence, artificial intelligence and law, technological attitude to legal knowledge.

\section{$\operatorname{sos}$}

